\title{
A Rare Complication of Transurethral Resection of the Prostate: Explosion of the Bladder
}

\section{Prostatın Transüretral Rezeksiyonunda Nadir Bir Komplikasyon: Mesane Patlaması}

\author{
İbrahim Buldu1, Tuna Karatağ1, Mehmet Kaynar2, M. Okan İstanbulluoğlu1 \\ 1 Mevlana University Faculty of Medicine, Department of Urology, Konya, Turkey \\ 2Selçuk University Faculty of Medicine, Department of Urology, Konya, Turkey
}

\begin{abstract}
Monopolar and bipolar transurethral resection of the prostate is currently the gold standard modality in the treatment of bladder outlet obstruction due to prostatic enlargement. A rare complication of transurethral resection is the explosion of the bladder as may occur during resection of the prostate. The etiology of explosion is thought to be a result of ignition due to mixture of oxygen and hydrogen gas occurring during the resection under increased pressure of the bladder. To the best of our knowledge, our case is the first report of bladder explosion during transurethral resection with bipolar energy using saline solution.
\end{abstract}

\section{Key Words}

Explosion, bladder, prostate, resection

\section{ÖZET}

Benign prostat hiperplazisinin tedavisinde altın standart yöntem monopolar veya bipolar metodla yapılan transüretral rezeksiyondur. Nadir bir komplikasyon olan mesane patlaması sıklıkla prostat rezeksiyonu esansında ortaya çıkar. Etyolojisinin rezeksiyon esnasında ortaya çıkan hidrojen gazının artmış mesane basıncı altında oksijen ile karışarak ateşlenmesi sonucu patlamanın meydana geldiği düşünülmektedir. Sunacağımız olguda bipolar enerji ve salin solüsyon kullanılarak transüretral rezeksiyon yapılırken mesane patlaması komplikasyonu gelişmesi ilk defa bildirilecektir.

\section{Anahtar Kelimeler}

Patlama, mesane, prostat, rezeksiyon

\section{Introduction}

Transurethral resection of the prostate (TURP) is currently the gold standard modality for the treatment of bladder outlet obstruction due to prostatic enlargement in size of 30-80 ml. Commonly, two modalities as monopolar and bipolar have been used for resection (1). A rare complication of transurethral resection is the explosion of the bladder as may occur during resection of the prostate $(2,3,4,5,6,7,8,9)$. The underlying mechanism for the explosion is thought to be a result of ignition due to mixture of oxygen and hydrogen gases occurring during the resection under increased pressure of the bladder (10). Explosion of the bladder usually requires surgical repair as that might cause a serious complication. To the best of our knowledge, our case is the first report of bladder explosion during transurethral resection with bipolar energy using saline solution.

\section{Case Report}

A 73-year-old male patient with a history of alpha- anta-agonist therapy for two years was referred to our clinic due to increased severity of lower urinary tract symptoms. Rectal examination revealed an enlarged benign prostate while the PSA level was $3.84 \mathrm{ng} / \mathrm{ml}$ and IPSS score was 28 . The upper urinary tracts were intact and prostate volume was measured as $77 \mathrm{~g}$ during ultrasonographic evaluation. The urinalysis was normal while serum creatinine was $1.9 \mathrm{mg} / \mathrm{dl}$. The uroflowmetry parameters were found to be $7 \mathrm{ml} / \mathrm{s}$ for maximum flow rate and $4 \mathrm{ml} / \mathrm{s}$ for average flow rate with a post-void residual urine of $150 \mathrm{ml}$. The patient underwent TURP using a $26 \mathrm{~F}$ resectoscope and bipolar energy source under spinal anesthesia (Autoconn II 400, Karl Storze, 296-395.9 Watt). Saline solution (0.9\% $\mathrm{NaCl})$ was used for irrigation as the power source of energy was set to five effect. A sudden and severe sound of explosion was heard towards the end of

\section{Correspondence}

Ibrahim Buldu MD, Mevlana University Faculty of Medicine, Department of Urology, Konya, Turkey

E-mail: ibrahimbuldu@yahoo.com Received: 24.01.2015 Accepted: 02.02.2015 
the operation (approximately 60 minutes later) during the resection of the prostate close to the bladder neck at the 12 o'clock position. Petechial hemorrhages and oil droplets were seen both inside and on the surface of the bladder. Therefore, we performed a cystogram in case of a possible bladder explosion. We observed the extravasation of contrast material through out of the bladder and disruption of the bladder wall (Figure 1). The patient underwent a retroperitoneal open surgery for primary repair. An irregular defect of the posterior bladder with a size of $8 \times 8 \mathrm{~cm}$ was observed (Figure 2). Mucosa and muscle tissue were sutured separately as two layers. The posterior surface of the bladder and intestines were also checked for the possibility of injury to the intraperitoneal organs. There was no injury to other organs and the operation was finished after inserting a threeway Foley urethral catheter and a cystostomy tube to the bladder together with a drainage catheter. The patient was discharged after cystostomy catheter removal on day 2 and drainage catheter on day 3 postoperatively. The Foley urethral catheter was also taken out after demonstrating no extravasation at the images of cystogram on day 10 postoperatively. Moreover, the patient urinated normally (Figure 3).

\section{Discussion}

An important disadvantage of monopolar TURP (M-TURP) in terms of developing of TUR syndrome is eliminated by bipolar TURP (B-TURP) depending on using normal saline solution. The basic principle of $\mathrm{B}$-TURP is based on reducing tissue resistance by creating plasma in the prostate with sodium ions in saline solution. Prostate tissue resection can be performed easily with low voltage after creating plasma. In this way, the development of TUR syndrome is eliminated in addition to less bleeding and less clot retention. Moreover, the durations of irrigation, catheterization, and hospitalization may be reduced (1).

Although explosion of the bladder is a rare complication, it may be observed during transurethral resection of both prostate and bladder tumors $(4,8) .1 .5 \%$ glycine, $3 \%$ mannitol or sterile water were used for irrigation in the cases reported previously $(3,4,5,6,7,8)$. Electrocauterization was performed using a unipolar power source of $80-120$ Watt. In this present case, saline fluids $(0.9 \% \mathrm{NaCl})$ were used for irrigation and energy source was achieved using bipolar electrocauterization unlike that in other reports.

According to a proposed theory, pyrolysis occurs in tissues during the resection as a wide variety of gases particularly hydrogen may arise (11). However, another theory is that hydrogen gas is derived from electrolysis of intracellular water (10). Next, it is thought to be that hydrogen gases interact with atmospheric oxygen gas in pressure and explosion occurs due to ignition with electrocoagulation. Hydrogen which is non-explosive alone, acquires flammable and explosive features when mixed with oxygen. The amount of gases accumulated in the bladder increases with a long duration of TUR process (12). Moreover, atmospheric oxygen gas enters into the bladder through the irrigation of the bladder with evacuator during the TUR process. If these gases are not emptied intermittently or continuously, this situation may pose a risk for explosion. Using a high level of energy may also lead to more dangerous status. Therefore, working with lowest possible energy as well as emptying the bladder intermittently during the TUR procedure can reduce the risk of developing this complication.

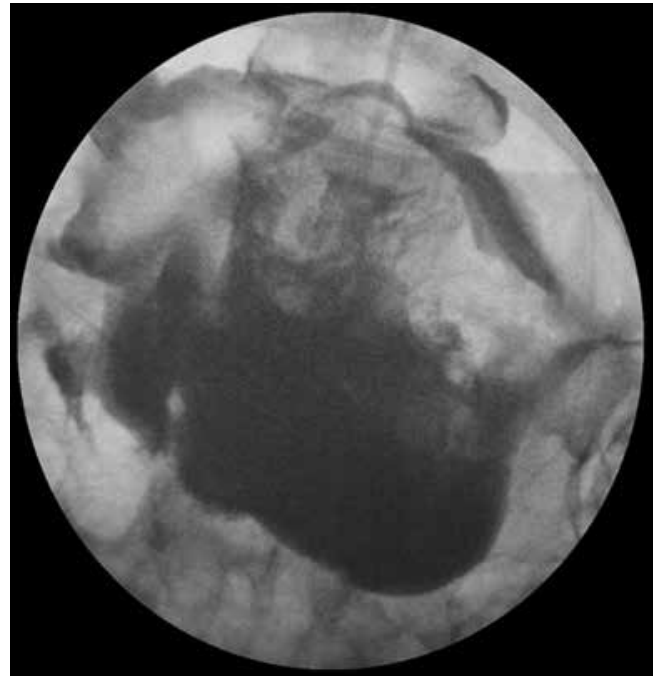

Figure 1. Cystogram image taken after the explosion

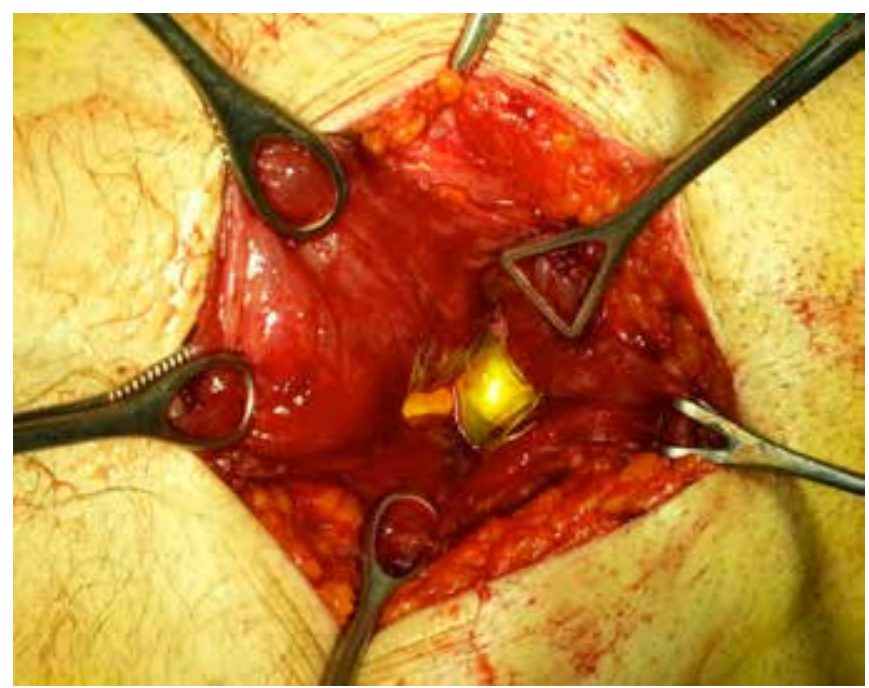

Figure 2. Showing the defect of bladder while repairing. See edematous and hemorrhagic appearance of bladder wall

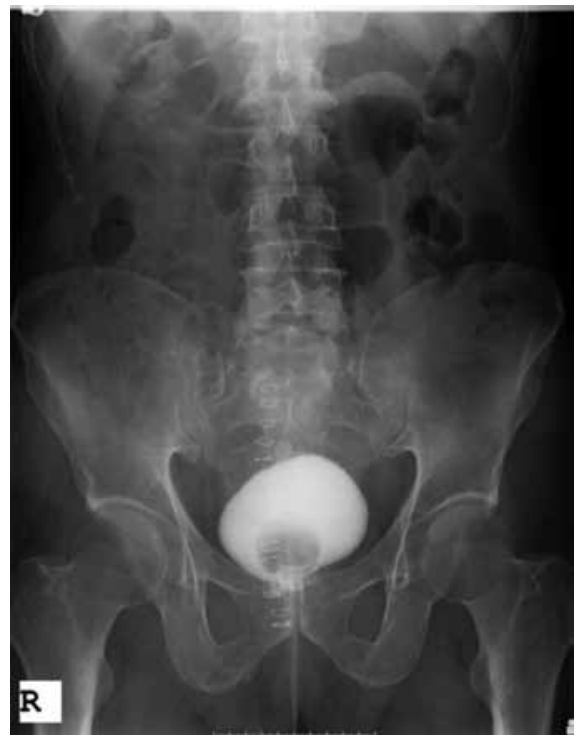

Figure 3. Cystogram image of post-operative on day 10 


\section{Conclusion}

A dangerous gas formation leading to explosion may occur during resection, regardless of types of irrigation fluid and electrocoagulation, should be considered when performing TUR procedures. Although it seems to be possible to prevent formation of gas during resection, we assume that emptying the bladder intermittently during TUR procedures may prevent a possible explosion.

Concept: Okan İstanbulluoğlu

Design: İbrahim Buldu, Tuna Karatağ

Data Collection or Processing: Ibrahim Buldu, Tuna Karatağ

Analysis or Interpretation: İbrahim Buldu, Tuna Karatağ

Literature Search: Mehmet Kaynar

Writing: Ibrahim Buldu

Peer-review: Externally peer-reviewed.

Conflict of Interest: No conflict of interest was declared by the authors.

Financial Disclosure: The authors declared that this study has received no financial support.

\section{References}

1. Gravas S, A. Bachmann, A. Descazeaud, M. Drake, C. Gratzke, S. Madersbacher, Mamoulakis, M. Oelke, K.A.O. Tikkinen. Guidelines On The Management Of Non-Neurogenic Male Lower Urinary Tract Symptoms
(LUTS), Incl. Benign ProstaticObstruction (BPO). European Association Of Urology, 2014, p62-66.

2. Khan A, Masood J, Ghei M, Kasmani Z, Ball AJ, Miller R. Intravesical Explosions During Transurethral Endoscopic Procedures. Int Urol Nephrol 2007;39:179-183.

3. Ribeiro da Silva MN, Lopes Neto AC, Zambon JP, Verotti MJ, Wroclawski ER. VesicalExplosionDuring Transurethral Resection of The Prostate: Report Of A Case. Arch Esp Urol 2006;59:651-652.

4. Srivastav a A, Sandhu AS, Sinha T, Madhusoodan an P, Karan S C, Sethi GS, Talwar R, Narang V. Intravesical ExplosionDuring Transurethral Resection Of Prostate -A Reminder. Urol Int 2006;77: 92-93.

5. Di Tonno F, Fusaro V, Bertoldin R, Lavelli D. Bladder Explosion During TransurethralResection Of The Prostate. Urol Int 2003;71:108-109.

6. Horger DC, Babanoury A. Intravesical ExplosionDuring Transurethral Resection of BladderTumors. J Urol 2004;172:1813.

7. Mohammadzadeh Rezaee M. Intravesical Explosion During Endoscopic TransurethralResection of Prostate. Urol J 2006;3:109-110.

8. Oğuz G, Subaşı D, Kaya M, Güven O, Ünver S. Intravesical Explosion: A Rare ComplicationOf Transurethral Resection Of Prostate. J Anesth 2013;27:154-146.

9. Dublin N, Razack AH, Loh CS. Intravesical Explosion During Transureth ral Resection Of The Prostate. ANZ J Surg 2001;71:384-385.

10. Ning TC Jr, Atkins DM, Murphy RC. Bladder Explosions During Transurethral Surgery. J Urol 1975;114:536-539.

11. Davis TR. The Composition And Origin Of The Gas Produced During UrologicalEndoscopic Resections. Br J Urol 1983;55:294-297.

12. Weston R, Stephenson RN, Kutarski PW, Parr NJ. ChemicalComposition of Gases Surgeons are Exposed to During Endoscopic Urological Resections. Urology 2009;74:1152-1154. 